\title{
Tres Poemas Olvidados
}

\section{JOSE MARIA EGUREN}

Como adición a nuestra compilación de Poesias completas de José Maria Eguren (Lima U. N. M. S. M. 1961) publicamos a continuación tres poe. mas no recopilados del gran poeta.

E. N.

\section{Y DANIRA CALLO}

¡Noche callada!

¡Noche de luna airada!

En mi aposento oscuro

sobre la mesa trípode las manos coloqué

y un diligente espiritu evoqué.

¿Quién eres le preguntolli Converso»

oh piadoso difunto

que vives en el aire coil aparente calma?

¿Dime qué nombre tienes

espíritu que vienes

hoy que está sola mi alma?

$\mathrm{Y}$ responde: En la tierra

me llamaban Danira

vi la luz en Palmira

que el hombre fiero ha scpultado,

fuí fugaz en la tierra y he muerto en pecado

Dime, ser evocado,

si en tu vida mortuoria

conservas de la dicha la memoria.

Gocé abajo el querer de unas miradas

de brillantes avenidas,

Letras, Lima 40 (80-81): 84-87, 1968 
mansiones plateadas, las puertas de oro, guarnecidas

y las columnas estriadas, emblemas color de rosa, sortijas perfumadas y como un tesoro mi carro de oro.

En la paz y en las treguas

como raudos corrían mis desbocadas yeguas

y en mi invariable amor se esclarecían

las galanuras

ae este país dorado,

cómo mis ojos esplendían

al mirar las locuras

de mi guerrero amado!

$\mathrm{Y}$ en la ciudad del antiguo Belo

en la cámara ciega

del amor me cantó anhelos

y me adormía con la flauta griega

a las dulces fragancias

del fino pebetero arcano.

Venturosas constancias

me prometía el centurión pagano!

Oh, sus cortejos de primavera

en el mundo la dicha se nombra

pero jay! si vivieras

en esta sombra!

¡Celeștial creación,

que me escuchas amable

y recuerdas que en un país dorado

de un amor invariable

acarició la muerte tu talle inmaculado!

¡oh tú piadosa bella

que Danira te nombras,

díme si me amara ella

en ese triste mundo de ias sombras,

dime, oculta deidad clemente,

si eternamente

será de amor su dulce mirada,

dije, iy la mesa retembló callada!.

(Publicada en La Prensa de Lima, 8 de Agosto 1916) 


\section{BALADA}

En el mirador

Las hijas del duende

Murmuran amor.

Por el ventanal

Se miran sus talles

De rosa percal.

En ronda rondín

La brisa les bebe

$\mathrm{Su}$ olor aserrín.

Con suave candor

Las hijas del duende

Cintilan de amor.

En el viejo altar

De la sacristía

Se quieren casar.

Con traje español

Que lleva bordados

La luna y el sol. le tias

"Jorge Puccinelli Converso"

Se pierde al desliz

El tiempo fantasma

El tiempo feliz.

Son galas de ayer,

Las hijas del duende

Sabían querer.

(Publicada en El Comercio de Lima, domingo 9 de febrero de 1930, en Palabra, época II, N` 6 julio de 1944, p. 5) 


\section{INVERNAL}

Desde los perfiles

del día entreabierto

se acerca una sombra

de jilguero muerto.

Con sus osamentas

de lirios azules

y en la noche sterna

sus ojos helados;

su fantasmagoria,

sus oscuraciones

nos dan la penumbra

de yertas canciones.

...Por los matizales,

por las arboledas

siguen una muerta

Bique nunca ha pasado.

"Jorge Puccinelli Converso"

(Publicado en Argonauta revista dirigida por: Melva Luna, número único 1955. p. 49-50) 